\title{
Cancer diagnosis, risk assessment and prediction of therapeutic response by means of DNA methylation markers
}

\author{
Heidi Fiegl ${ }^{\mathrm{a}, \mathrm{b}, *}$ and Karim Elmasry ${ }^{\mathrm{a}}$ \\ ${ }^{a}$ Translational Research Laboratory, Department of Gynaecological Oncology, Institute of Women's Health, UCL, \\ London, UK \\ ${ }^{\mathrm{b}}$ Biocentre Innsbruck, Division of Cell Biology, Medical University Innsbruck, Austria
}

\begin{abstract}
Epigenetic alterations are heritable changes in gene expression without an accompanying change in primary DNA sequence. Two major mechanisms that cause epigenetic changes are post-translational histone modifications and DNA methylation at cytosine bases within a $\mathrm{CpG}$ dinucleotide. Epigenetic defects have turned out to be one of the most common molecular alterations in human neoplasia. Promoter hypermethylation is associated with loss of expression of tumour suppressor genes in cancer. The analysis of aberrant DNA methylation is gaining strength in the fields of cancer risk assessment, diagnosis, and therapy monitoring in different cancer types. These issues are discussed in this review.
\end{abstract}

Keywords: Methylation, cancer risk assessment, diagnostics, prediction

\section{Introduction}

Cytosine methylation occurs after DNA synthesis by enzymatic transfer of a methyl group from the methyl donor S-adenosylmethionine to the carbon-5 position of cytosine. Cytosines are methylated in the human genome mostly when located 5' to a guanosine. CpG dinucleotides appear at about 5-fold lower than expected frequency in the overall genome [13]. Small regions with a high $\mathrm{G}: \mathrm{C}$ content, so-called $\mathrm{CpG}$ islands, are an exception to this observation. It has been estimated that half of all human genes contain $\mathrm{CpG}$ islands [3]. The generally accepted definition of a CpG island was proposed in 1987 by Gardiner-Garden and Frommer. They defined it as a 200-bp stretch of DNA with a $\mathrm{G}+\mathrm{C}$ content of $50 \%$ and an observed

\footnotetext{
* Corresponding author: Heidi Fiegl, Translational Research Laboratory, Department of Gynaecological Oncology, Institute of Women's Health, Windeyer Building, 46 Cleveland Street, London W1T 4JF, UK. Tel.: +44 20 76799495; Fax: +44 20 76799243; E-mail: Heidi.Fieg1@uibk.ac.at.
}

CpG/expected $\mathrm{CpG}$ in excess of 0.6 [27]. Takai and Jones used the complete genomic sequences of human chromosomes 21 and 22 to examine the properties of $\mathrm{CpG}$ islands in different sequence classes [88]. They found that regions of DNA of greater than $500 \mathrm{bp}$ with a $\mathrm{G}+\mathrm{C}$ equal to or greater than $55 \%$ and observed $\mathrm{CpG} /$ expected $\mathrm{CpG}$ of 0.65 were more likely to be associated with the 5 ' regions of genes and this definition excluded most Alu-repetitive elements.

Promoter methylation is generally inversely correlated with gene expression (Fig. 1). The repression is caused on the one hand by changes in chromatin structures due to binding of specific proteins to methylated DNA and on the other hand by decreased affinity of some transcription factors for methylated $\mathrm{CpG}$ sites.

In normal tissues de novo methylation of 5' $\mathrm{CpG}$ islands rarely occurs. In addition to imprinted genes and inactive $\mathrm{X}$-chromosomal genes, $\mathrm{CpG}$ islands associated with non-imprinted autosomal genes can show gradual increases in methylation during ageing $[43,44]$. It has been increasingly recognized over the past few years that the $\mathrm{CpG}$ islands of many genes, which are mostly 
A

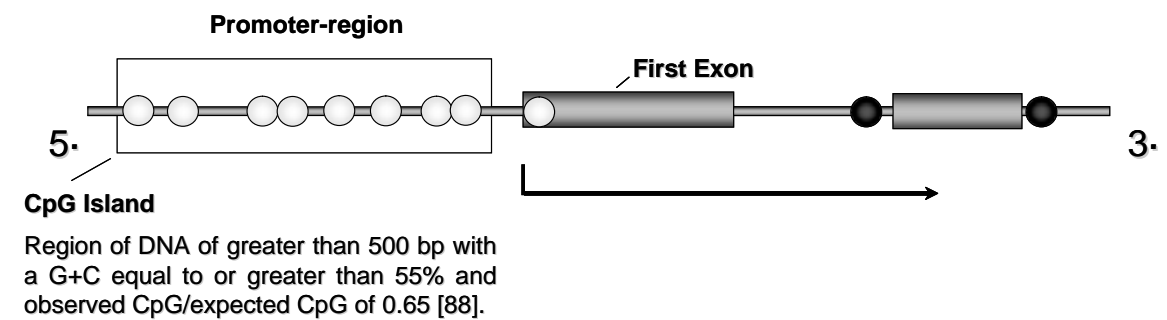

B

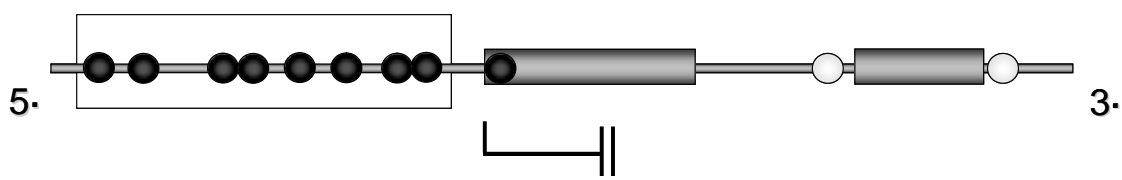

Fig. 1. Methylation and gene expression. (A) In a normal cell no methylation at CpG sites (white circles) in CpG islands occurs, whereas most of the $\mathrm{CpG}$ sites in the rest of the genome are methylated (black circles). (B) During carcinogenesis the CpG sites in the CpG islands of tumour suppressor genes become hypermethylated, which lead to repression of the mRNA expression, whereas the rest of the CpG sites outside the islands becomes hypomethylated.

unmethylated in normal tissue, are hypermethylated to various degrees in human cancers, thus representing tumour-specific alterations [47,57]. In addition, overall genome hypomethylation is present in most tumours. Hypomethylation of repeated or single-copy DNA sequences has been significantly correlated with disease progression for some tumours $[77,79,80]$.

There are different principles of DNA methylation analysis such as determination of the methylation content, level or pattern. DNA methylation can be detected either by methods which use methylation-sensitive restriction enzymes or by methods which use the so called Sodium Bisulfite modification of genomic DNA [57]. The latter group of methods comprises techniques such as Methylation specific PCR (MSP) [35], MethyLight [21], or Oligo microarrays [1,4], and are mostly used in clinical studies. The basis of Sodium Bisulfite conversion of genomic DNA is the deamination of unmethylated cytosines to uracils, which allows discrimination between methylated and unmethylated cytosines (Fig. 2).

Methylation based markers have an enormous potential in (1) cancer risk assessment, (2) early detection, and (3) therapy monitoring. These applications are discussed below.

\section{DNA methylation and cancer risk assessment}

The identification of patients who are at high risk of cancer through screening could be very helpful for prophylactic treatment. The use of aberrant methylation as a cancer risk marker seems to be promising as recent publications show. Loss of imprinting (LOI) is an epigenetic alteration of some cancers involving loss of parental origin-specific expression of imprinted genes. Cui et al. found that about one-third of colorectal cancers undergo LOI, and that LOI is also found in the matched normal colon of the same patients [15]. To prove that LOI was not simply a developmental alteration unrelated to cancer, the authors analyzed the normal colon of patients without colorectal cancer, and found that the frequency of LOI was threefold greater in cancer patients. Furthermore it was shown that LOI could also be detected in all blood samples from the analyzed patients whereas only $12 \%$ of the control patients without cancer showed LOI in colonic mucosa and $13 \%$ in blood samples respectively. In a further study, where the authors investigated the utility of LOI as a marker of colorectal cancer risk, LOI in peripheral lymphocytes was also associated with an increased risk [14]. These data suggest that LOI may identify an important subset of the population with cancer or at an increased risk of developing cancer. The authors suggest creating a DNA methylation based blood test for the detection of individuals who are at high risk for colorectal cancer.

Another study where the role of the methylation of $M L H 1$, a DNA mismatch repair gene, in the normal colonic mucosa of patients with colorectal cancer was analysed, showed that methylation of this gene in- 
<smiles>Nc1cc[nH]c(=O)n1</smiles>

Cytosine<smiles>NC1=NC(=O)NC([Se]O)C1</smiles>

Cytosine Sulfonate<smiles>NC(CO)CO</smiles><smiles>O=C1CC(S(=O)(=O)O)NC(=O)N1</smiles>

Uracil Sulfonate<smiles></smiles>

Uracil

Fig. 2. During Sodium Bisulfite modification of genomic DNA an unmethylated cytosine is converted to an uracil by a three step process which comprises (1) a sulfonation, (2) a hydrolytic deamination and (3) an alkali desulfonation. Methylated cytosines are protected from this conversion. By this mechanism discrimination between methylated and unmethylated cytosines is possible by differences in the sequence.

creases with age, and correlates with the occurrence of tumours which are positive for microsatellite instability [72]. DNA-Methylation in normal colon might predispose the tissue directly to cancer. Thus DNA methylation has also been proposed as a candidate mediator of field defects, leading to cancer.

Germline epimutations are thought to be a basis for epigenetic disease in humans. Suter et al. hypothesized that some individuals are predisposed to develop cancer because they carry germline epimutations of tumor suppressor genes [86]. They report two patients, who fit the criteria for hereditary nonpolyposis colorectal carcinoma (HNPCC), with soma-wide, allele-specific and mosaic hypermethylation of $M L H 1$ and no evidence of genetic mutations in mismatch repair genes. One patient had this epimutation also in the spermatozoa, indicating a germline defect and the potential for transmission to offsprings. Epigenetic phenomena tend to be stochastic, mosaic, and reversible. The rules for the occurrence and inheritance of epimutations are probably completely different from those of Mendelian genetics. A recent study where the frequency and role of germline epimutations of MLHI in HNPCC was determined, shows that the inheritance of epimutations is weak, which is why family history is not a useful guide for screening [37]. Germline epimutations should be suspected in younger individuals without a family history who present with a microsatellite unstable tumour showing loss of $M L H 1$ expression.

These facts show the possible power of aberrant DNA-methylation for the development of screening tests to predict the individual risk for different types of cancer.

\section{DNA methylation and diagnostics}

DNA methylation has several advantages over protein markers, RNA or mutations. Firstly, the methyla- tion signal can be amplified and therefore DNA methylation analysis by PCR is very sensitive. Secondly, DNA is a very stable molecule in comparison to protein or RNA. In addition, DNA hypermethylation takes place in a defined area of the gene- the CpG island in the promoter region, whereas mutations can take place in various regions of a gene. For these reasons methylation analysis seems to be a promising tool in molecular diagnostics.

For most types of cancer, early detection of the disease is associated with an improved clinical outcome. Because DNA methylation changes have been reported to occur early in carcinogenesis [56], the identification of aberrant DNA methylation offers the exciting possibility of developing diagnostic tests.

The early detection of cancer by methylation markers is based on the premise that tumour-derived DNA is released into body fluids or other remote samples and is detected by the abnormal DNA methylation patterns specific for malignant cells [58]. It is thought that tumour DNA in luminal samples (sputum, urine, stool, vaginal fluid and lavage) is derived from cells which are sloughed off from the tumour. There are several hypotheses regarding how free circulating DNA can enter the blood system. One possibility could be that free circulating DNA derives from circulating tumour cells. It is assumed that DNA enters the plasma following lysis of cells on the interface between the primary tumour and the circulation, breakdown of circulating cancer cells or destruction of tumour micrometastases. Stroun et al. showed that 10.000 tumour cells per millilitre blood would be necessary to account for the amount of free DNA circulating in blood of cancer patients [84]. This indicates that circulating tumour cells would be a poor explanation for free circulating DNA. In addition to cell lysis, apoptosis has been proposed as the origin of circulating DNA [28]. However, the phenomenon 
of spontaneous active release of DNA from cells might also be expected.

Many studies have used serum or plasma to detect aberrant DNA methylation in breast $[19,41,71,81,82]$, colorectal $[33,45,59,63,73,100]$, lung $[2,5,6,22,26,55$, 65,90], head and neck [78,87,98,99], esophageal [36], liver [12,67,95-97], gastric [10,42,49,51,52,60,62, $66]$, prostate $[34,74]$, bladder cancer $[18,91]$ and melanoma $[39,68]$. In recent years other sources of DNA have been analysed. Vaginal secretions on tampons for the detection of endometrial cancer [23] and cervical cancer [94], nipple aspirate fluid [54], breast fine needle washings [46] for breast cancer, sputum [6, $38,53,75,93]$, bronchial brush samples [83] and bronchioalveolar lavage $[8,17,50,89]$ for lung cancer, prostatic fluid [31], ejaculate [30,85], urine [32] and urine sediment [40] for prostate cancer, urine $[9,20]$ or urine sediments [25] for bladder cancer, peritoneal fluid [16, 69] for ovarian cancer and stool for the detection of colon cancer $[7,11,61,64,70,76]$.

\section{DNA Methylation and prediction of response to therapy}

Some papers show that the methylation status of individual genes or patterns of multiple genes are associated with disease prognosis and response to therapeutics. Methylation markers which can identify subtypes of cancer could be useful in the choice of treatment. A recently published work describes methylation patterns specific for glioma grade and glioma subtypes [90].

Adjuvant systemic therapy (a strategy that targets potential disseminated tumour cells after complete removal of the tumour) has clearly improved survival of cancer patients. To date no tool is available to monitor efficacy of these therapies, unless distant metastases arise, a situation that eventually leads to death. A study where the $\mathrm{CpG}$ island methylator phenotype (CIMP) status, characterized by concurrent methylation of multiple $\mathrm{CpG}$ islands in tumour DNA, was evaluated in 103 stage III colorectal cancer samples from patients treated with surgery alone and in an additional 103 cases from patients treated with surgery and adjuvant 5-fluorouracil-based chemotherapy. This showed that CIMP has independent predictive significance for the survival benefit from adjuvant 5-fluorouracil (5-FU) chemotherapy in colorectal cancer [92]. The authors concluded that a positive CIMP has independent predictive significance for the survival benefit from 5-FU chemotherapy in colorectal cancer and that this molecu- lar marker should be incorporated into prospective clinical trials of fluorouracil-based therapies to confirm its clinical value. Recently in a study of 148 patients with breast cancer receiving adjuvant therapy the measurement of serum DNA methylation of RASSF 1A was used to monitor treatment efficacy [24]: Disappearance of RASSF 1A DNA methylation in serum throughout treatment with tamoxifen indicates a response, while persistence or new appearance means resistance to adjuvant tamoxifen treatment.

In a study of 47 melanoma patients who received biochemotherapy it was shown that detection of circulating methylated RASSFIA DNA in serum can predict response to the biochemotherapy and disease outcome [68].

DNA methylation is potentially an important driving force for drug resistance. There is growing evidence that DNA methylation of genes, which are directly involved in drug responses, has a potential role in predicting disease outcome following chemotherapy. The analysis of $\mathrm{MLH1}$ methylation in plasma samples of ovarian cancer patients before chemotherapy and at relapse showed that $25 \%$ of patients acquired $M L H 1$ methylation during chemotherapy, which was independently associated with poor overall survival [29].

It remains to be seen whether modifications made in adjuvant therapeutic strategies based on detection of circulating nucleic acids will improve survival as well as quality of life.

\section{Conclusion}

Over the past few years the field of epigenetics in cancer has moved centre stage. It has become apparent that cancer is as much a disease of aberrant epigenetics as it is a disease of genetic mutations. Epigenetic silencing is now recognized as a "Third pathway" in Knudson's model of tumour-suppressor gene interaction in cancer. Knudson's hypothesis that two hits are required for the full inactivation of a tumour-suppressor gene has been shown to be fundamentally correct in almost all cases of human cancer. So the suggested pathways for the inactivation of tumour suppressor genes are intragenic mutations, loss of chromosomal material (loss of heterozygosity ( $\mathrm{LOH}$ ) or homozygous deletion) and DNA methylation [48].

The ubiquity of DNA methylation changes has opened the way to risk assessment, early detection, molecular diagnostic of resected specimens, chemoprevention and monitoring for disease recurrence. How- 
ever, if we are to use these changes in cancer diagnostics or even to modify epigenetic information with demethylating agents, we must gain more insight into the mechanisms that underlie the DNA methylation changes in cancer cells.

The different methods for detecting methylation markers are not as yet validated and standardized. But a successful clinical diagnostic assay requires careful consideration of several issues. Firstly optimal sample quality is a prerequisite to generate valid quantitative data. Hence sample collection, transport and preparation are all critical parameters in test performance and must be optimized and standardized. Secondly analytical sensitivity and specificity are critical parameters of any diagnostic assay. Analytical sensitivity refers to the smallest number of molecules that can be detected and distinguished from a zero result. Analytical specificity is determined by the degree to which analytes other than that in question react in an assay; the higher the level of cross-reactions, the lower the analytical specificity. Finally there must be agreement between replicates within and between runs of the assay, as this provides important information about the reliability of the assay. Repeatability is measured as the amount of agreement between replicates tested in different analysis. Reproducibility is determined in several laboratories using the identical assay (protocol, reagents and controls). It is important to maintain the internal quality control by monitoring the assay for both parameters. Therefore the protocols for sample preparation and analysis must meet strict requirements for consistency and performance.

Epigenetic markers are now under clinical trials. Based on the published studies it appears that methylation markers will play an exciting role in cancer in the future.

\section{References}

[1] P. Adorjan, J. Distler, E. Lipscher, F. Model, J. Muller, C. Pelet, A. Braun, A.R. Florl, D. Gutig, G. Grabs, A. Howe, M. Kursar, R. Lesche, E. Leu, A. Lewin, S. Maier, V. Muller, T. Otto, C. Scholz, W.A. Schulz, H.H. Seifert, I. Schwope, H. Ziebarth, K. Berlin, C. Piepenbrock and A. Olek, Tumour class prediction and discovery by microarray-based DNA methylation analysis, Nucl Acids Res 30 (2002), e21.

[2] Q. An, Y. Liu, Y.N. Gao, J.F. Huang, X.L. Fong, L. Li, D.C. Zhang and S.J. Cheng, Detection of p16 hypermethylation in circulating plasma DNA of non-small cell lung cancer patients, Cancer Lett 188 (2002), 109-114.

[3] F. Antequera and A. Bird, Number of CpG islands and genes in human and mouse, Proc Natl Acad Sci USA 90 (1993), 11995-11999.
[4] R.P. Balog, Y.E.P. de Souza, H.M. Tang, G.M. DeMasellis, B. Gao, A. Avila, D.J. Gaban, D. Mittelman, J.D. Minna, K.J. Luebke and H.R. Garner, Parallel assessment of CpG methylation by two-color hybridization with oligonucleotide arrays, Anal Biochem 309 (2002), 301-310.

[5] A. Bearzatto, D. Conte, M. Frattini, N. Zaffaroni, F. Andriani, D. Balestra, L. Tavecchio, M.G. Daidone and G. Sozzi, p16INK4A Hypermethylation Detected by Fluorescent Methylation-specific PCR in Plasmas from Non-Small Cell Lung Cancer, Clin Cancer Res 8 (2002), 3782-3787.

[6] S.A. Belinsky, D.M. Klinge, J.D. Dekker, M.W. Smith, T.J. Bocklage, F.D. Gilliland, R.E. Crowell, D.D. Karp, C.A. Stidley and M.A. Picchi, Gene Promoter Methylation in Plasma and Sputum Increases with Lung Cancer Risk, Clin Cancer Res 11 (2005), 6505-6511.

[7] N.J. Belshaw, G.O. Elliott, E.A. Williams, D.M. Bradburn, S.J. Mills, J.C. Mathers and I.T. Johnson, Use of DNA from Human Stools to Detect Aberrant CpG Island Methylation of Genes Implicated in Colorectal Cancer, Cancer Epidemiol Biomarkers Prev 13 (2004), 1495-1501.

[8] E.C. Chan, S.Y. Lam, K.W. Tsang, B. Lam, J C.M. Ho, K.H. Fu, W.K. Lam and Y.L. Kwong, Aberrant Promoter Methylation in Chinese Patients with Non-Small Cell Lung Cancer: Patterns in Primary Tumors and Potential Diagnostic Application in Bronchoalevolar Lavage, Clin Cancer Res $\mathbf{8}$ (2002), 3741-3746.

[9] M.W.Y. Chan, L.W. Chan, N.L.S. Tang, J.H.M. Tong, K.W. Lo, T.L. Lee, H.Y. Cheung, W.S. Wong, P.S.F. Chan, F.M.M. Lai and K.F. To, Hypermethylation of multiple genes in tumor tissues and voided urine in urinary bladder cancer patients, Clin Cancer Res 8 (2002), 464-470.

[10] M.W.Y. Chan, E.S.H. Chu, K.F. To and W.K. Leung, Quantitative detection of methylated SOCS-1, a tumor suppressor gene, by a modified protocol of quantitative real time methylation-specific PCR using SYBR green and its use in early gastric cancer detection, Biotechnol Lett 26 (2004), 1289-1293.

[11] W.D. Chen, Z.J. Han, J. Skoletsky, J. Olson, J. Sah, L. Myeroff, P. Platzer, S. Lu, D. Dawson, J. Willis, T.P. Pretlow, J. Lutterbaugh, L. Kasturi, J.K.V. Willson, J.S. Rao, A. Shuber and S.D. Markowitz, Detection in Fecal DNA of Colon Cancer-Specific Methylation of the Nonexpressed Vimentin Gene, J Natl Cancer Inst 97 (2005), 1124-1132.

[12] H.J. Chu, J. Heo, S.B. Seo, G.H. Kim, D.H. Kang, G.A. Song, M. Cho and U.S. Yang, Detection of aberrant p16(INK4A) methylation in Sera of patients with liver cirrhosis and hepatocellular carcinoma, J Korean Med Sci 19 (2004), 83-86.

[13] D.N. Cooper and M. Krawczak, Cytosine methylation and the fate of $\mathrm{CpG}$ dinucleotides in vertebrate genomes, Hum Genet 83 (1989), 181-188.

[14] H.M. Cui, M. Cruz-Correa, F.M. Giardiello, D.F. Hutcheon, D.R. Kafonek, S. Brandenburg, Y.Q. Wu, X.B. He, N.R. Powe and A.P. Feinberg, Loss of IGF2 imprinting: A potential marker of colorectal cancer risk, Science 299 (2003), 1753-1755.

[15] H.M. Cui, I.L. Horon, R. Ohlsson, S.R. Hamilton and A.P. Feinberg, Loss of imprinting in normal tissue of colorectal cancer patients with microsatellite instability, Nat Med 4 (1998), 1276-1280.

[16] I.I. de Caceres, C. Battagli, M. Esteller, J.G. Herman, E. Dulaimi, M.I. Edelson, C. Bergman, H. Ehya, B.L. Eisenberg and P. Cairns, Tumor Cell-Specific BRCA1 and RASSF1A Hypermethylation in Serum, Plasma, and Peritoneal Fluid 
from Ovarian Cancer Patients, Cancer Res 64 (2004), 64766481.

[17] F. de Fraipont, D. Moro-Sibilot, S. Michelland, E. Brambilla, C. Brambilla and M.C. Favrot, Promoter methylation of genes in bronchial lavages: A marker for early diagnosis of primary and relapsing non-small cell lung cancer? Lung Cancer 50 (2005), 199-209.

[18] G. Dominguez, J. Carballido, J. Silva, J.M. Silva, J.M. Garcia, J. Menendez, M. Provencio, P. Espana and F. Bonilla, p14ARF Promoter Hypermethylation in Plasma DNA as an Indicator of Disease Recurrence in Bladder Cancer Patients. Clin Cancer Res 8 (2002), 980-985.

[19] E. Dulaimi, J. Hillinck, I.I. de Caceres, T. Al Saleem and P. Cairns, Tumor Suppressor Gene Promoter Hypermethylation in Serum of Breast Cancer Patients, Clin Cancer Res 10 (2004), 6189-6193.

[20] E. Dulaimi, R.G. Uzzo, R.E. Greenberg, T. Al Saleem and P. Cairns, Detection of Bladder Cancer in Urine by a Tumor Suppressor Gene Hypermethylation Panel, Clin Cancer Res 10 (2004), 1887-1893.

[21] C.A. Eads, K.D. Danenberg, K. Kawakami, L.B. Saltz, C. Blake, D. Shibata, P.V. Danenberg and P.W. Laird, MethyLight: a high-throughput assay to measure DNA methylation, Nucl Acids Res 28 (2000), e32.

[22] M. Esteller, M. Sanchez-Cespedes, R. Rosell, D. Sidransky, S.B. Baylin and J.G. Herman, Detection of Aberrant Promoter Hypermethylation of Tumor Suppressor Genes in Serum DNA from Non-Small Cell Lung Cancer Patients, Cancer Res 59 (1999), 67-70.

[23] H. Fiegl, C. Gattringer, A. Widschwendter, A. Schneitter, A. Ramoni, D. Sarlay, I. Gaugg, G. Goebel, H.M. Muller, E. Mueller-Holzner, C. Marth and M. Widschwendter, Methylated DNA collected by tampons - A new tool to detect endometrial cancer, Cancer Epidemiol Biomarkers Prev 13 (2004), 882-888.

[24] H. Fiegl, S. Millinger, E. Mueller-Holzner, C. Marth, C. Ensinger, A. Berger, H. Klocker, G. Goebel and M. Widschwendter, Circulating tumor-specific DNA: A marker for monitoring efficacy of adjuvant therapy in cancer patients, Cancer Res 65 (2005), 1141-1145.

[25] M.G. Friedrich, D.J. Weisenberger, J.C. Cheng, S. Chandrasoma, K.D. Siegmund, M.L. Gonzalgo, M.I. Toma, H. Huland, C. Yoo, Y.C. Tsai, P.W. Nichols, B.H. Bochner, P.A. Jones and G. Liang, Detection of Methylated ApoptosisAssociated Genes in Urine Sediments of Bladder Cancer Patients, Clin Cancer Res 10 (2004), 7457-7465.

[26] K. Fujiwara, N. Fujimoto, M. Tabata, K. Nishii, K. Matsuo, K. Hotta, T. Kozuki, M. Aoe, K. Kiura, H. Ueoka and M. Tanimoto, Identification of Epigenetic Aberrant Promoter Methylation in Serum DNA Is Useful for Early Detection of Lung Cancer, Clin Cancer Res 11 (2005), 1219-1225.

[27] M. Gardinergarden and M. Frommer, Cpg Islands in Vertebrate Genomes, J Mol Biol 196 (1987), 261-282.

[28] M.B. Giacona, G.C. Ruben, K.A. Iczkowski, T.B. Roos, D.M. Porter and G.D. Sorenson, Cell-free DNA in human blood plasma: Length measurements in patients with pancreatic cancer and healthy controls, Pancreas 17 (1998), 89-97.

[29] G. Gifford, J. Paul, P.A. Vasey, S.B. Kaye and R. Brown, The Acquisition of hMLH1 Methylation in Plasma DNA after Chemotherapy Predicts Poor Survival for Ovarian Cancer Patients, Clin Cancer Res 10 (2004), 4420-4426.

[30] C. Goessl, H. Krause, M. Muller, R. Heicappell, M. Schrader, J. Sachsinger and K. Miller, Fluorescent methylation-specific polymerase chain reaction for DNA-based detection of prostate cancer in bodily fluids, Cancer Res 60 (2000), 59415945.

[31] M.L. Gonzalgo, M. Nakayama, S.M. Lee, A.M. De Marzo and W.G. Nelson, Detection of GSTP1 methylation in prostatic secretions using combinatorial MSP analysis, Urology 63 (2004), 414-418.

[32] M.L. Gonzalgo, C.P. Pavlovich, S.M. Lee and W.G. Nelson, Prostate Cancer Detection by GSTP1 Methylation Analysis of Postbiopsy Urine Specimens, Clin Cancer Res 9 (2003), 2673-2677.

[33] W.M. Grady, A. Rajput, J.D. Lutterbaugh and S.D. Markowitz, Detection of Aberrantly Methylated hMLH1 Promoter DNA in the Serum of Patients with Microsatellite Unstable Colon Cancer, Cancer Res 61 (2001), 900-902.

[34] R. Henrique and C. Jeronimo, Molecular detection of prostate cancer: A role for GSTP1 hypermethylation, Eur Urol $\mathbf{4 6}$ (2004), 660-669.

[35] J.G. Herman, J.R. Graff, S. Myohanen, B.D. Nelkin and S.B. Baylin, Methylation-specific PCR: A novel PCR assay for methylation status of CpG islands, Proc Natl Acad Sci USA 93 (1996), 9821-9826.

[36] K. Hibi, M. Taguchi, H. Nakayama, T. Takase, Y. Kasai, K. Ito, S. Akiyama and A. Nakao, Molecular Detection of p16 Promoter Methylation in the Serum of Patients with Esophageal Squamous Cell Carcinoma, Clin Cancer Res 7 (2001), 3135-3138.

[37] M. Hitchins, R. Williams, K. Cheong, N. Halani, V.A. Lin, D. Packham, S. Ku, A. Buckle, N. Hawkins, J. Burn, S. Gallinger, J. Goldblatt, J. Kirk, I. Tomlinson, R. Scott, A. Spigelman, C. Suter, D. Martin, G. Suthers and R. Ward, MLH1 germline epimutations as a factor in hereditary nonpolyposis colorectal cancer, Gastroenterology 129 (2005), 1392-1399.

[38] S. Honorio, A. Agathanggelou, M. Schuermann, W. Pankow, P. Viacava, E.R. Maher and F. Latif, Detection of RASSF1A aberrant promoter hypermethylation in sputum from chronic smokers and ductal carcinoma in situ from breast cancer patients, Oncogene 22 (2003), 147-150.

[39] D.S.B. Hoon, M. Spugnardi, C. Kuo, S.K. Huang, D.L. Morton and B. Taback, Profiling epigenetic inactivation of tumor suppressor genes in tumors and plasma from cutaneous melanoma patients, Oncogene 23 (2004), 4014-4022.

[40] M.O. Hoque, O. Topaloglu, S. Begum, R. Henrique, E. Rosenbaum, W. Van Criekinge, W.H. Westra and D. Sidransky, Quantitative Methylation-Specific Polymerase Chain Reaction Gene Patterns in Urine Sediment Distinguish Prostate Cancer Patients From Control Subjects, J Clin Oncol 23 (2005), 6569-6575.

[41] X.C. Hu, I.H.N. Wong and L.W.C. Chow, Tumor-derived aberrant methylation in plasma of invasive ductal breast cancer patients: Clinical implications, Oncol Reports 10 (2003), 1811-1815.

[42] D. Ichikawa, H. Koike, H. Ikoma, D. Ikoma, N. Tani, E. Otsuji, K. Kitamura and H. Yamagishi, Detection of aberrant methylation as a tumor marker in serum of patients with gastric cancer, Anticancer Res 24 (2004), 2477-2481.

[43] J.P.J. Issa, Y.L. Ottaviano, P. Celano, S.R. Hamilton, N.E. Davidson and S.B. Baylin, Methylation of the EstrogenReceptor Cpg Island Links Aging and Neoplasia in Human Colon, Nat Genet 7 (1994), 536-540.

[44] J.P.J. Issa, P.M. Vertino, C.D. Boehm, I.F. Newsham and S.B. Baylin, Switch from monoallelic to biallelic human IGF2 promoter methylation during aging and carcinogenesis, Proc Natl Acad Sci USA 93 (1996), 11757-11762. 
[45] S. Ito, K. Hibi, H. Nakayama, Y. Kodera, K. Ito, S. Akiyama and A. Nakao, Detection of tumor DNA in serum of colorectal cancer patients, Jpn J Cancer Res 93 (2002), 1266-1269.

[46] C. Jeronimo, I. Costa, M.C. Martins, P. Monteiro, S. Lisboa, C. Palmeira, R. Henrique, M.R. Teixeira and C. Lopes, Detection of Gene Promoter Hypermethylation in Fine Needle Washings from Breast Lesions, Clin Cancer Res 9 (2003), 3413-3417.

[47] P.A. Jones and S.B. Baylin, The fundamental role of epigenetic events in cancer, Nat Rev Genet 3 (2002), 415-428.

[48] P.A. Jones and P.W. Laird, Cancer epigenetics comes of age, Nat Genet 21 (1999), 163-167.

[49] Y. Kanyama, K. Hibi, H. Nakayama, Y. Kodera, K. Ito, S. Akiyama and A. Nakao, Detection of p16 promoter hypermethylation in serum of gastric cancer patients, Cancer Sci 94 (2003), 418-420.

[50] H. Kim, Y.M. Kwon, J.S. Kim, H. Lee, J.H. Park, Y.M. Shim, J. Han, J. Park and D.H. Kim, Tumor-Specific Methylation in Bronchial Lavage for the Early Detection of Non-Small-Cell Lung Cancer, J Clin Oncol 22 (2004), 2363-2370.

[51] H. Koike, D. Ichikawa, H. Ikoma, E. Otsuji, K. Kitamura and $\mathrm{H}$. Yamagishi, Comparison of methylation-specific polymerase chain reaction (MSP) with reverse transcriptasepolymerase chain reaction (RT-PCR) in peripheral blood of gastric cancer patients, J Surg Oncol 87 (2004), 182-186.

[52] H. Koike, D. Ichikawa, H. Ikoma, N. Tani, D. Ikoma, E. Otsuji, K. Okamoto, Y. Ueda, K. Kitamura and H. Yamagishi, Comparison of serum aberrant methylation and conventional tumor markers in gastric cancer patients, Hepatogastroenterology 52 (2005), 1293-1296.

[53] S. Konno, Y. Morishita, M. Fukasawa, Y.J. Shu, D.Y. Wang, R. Tanaka, Y. Minami, T. Iijima and M. Noguchi, Anthracotic index and DNA methylation status of sputum contents can be used for identifying the population at risk of lung carcinoma, Cancer 102 (2004), 348-354.

[54] R. Krassenstein, E. Sauter, E. Dulaimi, C. Battagli, H. Ehya, A. Klein-Szanto and P. Cairns, Detection of Breast Cancer in Nipple Aspirate Fluid by CpG Island Hypermethylation, Clin Cancer Res 10 (2004), 28-32.

[55] E. Kurakawa, T. Shimamoto, K. Utsumi, T. Hirano, H. Kato and K. Ohyashiki, Hypermethylation of p16(INK4a) and p15(INK4b) genes in non-small cell lung cancer, Int J Oncol 19 (2001), 277-281.

[56] P.W. Laird, Oncogenic mechanisms mediated by DNA methylation, Mol Med Today 3 (1997), 223-229.

[57] P.W. Laird, The power and the promise of DNA methylation markers, Nat Rev Cancer 3 (2003), 253-266.

[58] P.W. Laird, Cancer epigenetics, Hum Mol Genet 14 (2005), R65-R76.

[59] T. Lecomte, A. Berger, F. Zinzindohoue, S. Micard, B. Landi, H. Blons, P. Beaune, P.H. Cugnenc and P. Laurent-Puig, Detection of free-circulating tumor-associated DNA in plasma of colorectal cancer patients and its association with prognosis, Int J Cancer 100 (2002), 542-548.

[60] T.L. Lee, W.K. Leung, M.W.Y. Chan, E.K.W. Ng, J.H.M. Tong, K.W. Lo, S.C.S. Chung, J.J.Y. Sung and K.F. To, Detection of Gene Promoter Hypermethylation in the Tumor and Serum of Patients with Gastric Carcinoma, Clin Cancer Res 8 (2002), 1761-1766.

[61] K. Lenhard, G.T. Bommer, S. Asutay, R. Schauer, T. Brabletz, B. Goke, R. Lamerz and F.T. Kolligs, Analysis of promoter methylation in stool: A novel method for the detection of colorectal cancer, Clin Gastroenterol Hepatol 3 (2005), 142-149.
[62] W.K. Leung, K.F. To, E.S.H.Chu, M.W.Y. Chan, A.H.C. Bai, E.K.W. Ng, F.K.L. Chan and J.J.Y. Sung, Potential diagnostic and prognostic values of detecting promoter hypermethylation in the serum of patients with gastric cancer, Br J Cancer 92 (2005), 2190-2194.

[63] W.K. Leung, K.F. To, E.P.S. Man, M.W.Y. Chan, A.H.C. Bai, A.J. Hui, F.K.L. Chan and J.J.Y. Sung, Quantitative detection of promoter hypermethylation in multiple genes in the serum of patients with colorectal cancer, Am J Gastroenterol 100 (2005), 2274-2279.

[64] W. K. Leung, K.F. To, E.P.S. Man, M.W.Y. Chan, A.H.C. Bai, A.J. Hui, F.K.L. Chan, J.F.Y. Lee and J.J.Y. Sung, Detection of Epigenetic Changes in Fecal DNA as a Molecular Screening Test for Colorectal Cancer: A Feasibility Study, Clin Chem 50 (2004), 2179-2182.

[65] Y. Liu, Q. An, L. Li, D. Zhang, J. Huang, X. Feng, S. Cheng and Y. Gao, Hypermethylation of p16INK4a in Chinese lung cancer patients: biological and clinical implications, Carcinogenesis 24 (2003), 1897-1901.

[66] J.C. Machado, C. Oliveira, R. Carvalho, P. Soares, G. Berx, C. Caldas, R. Seruca, F. Carneiro and M. Sobrinho-Simoes, E-cadherin gene (CDH1) promoter methylation as the second hit in sporadic diffuse gastric carcinoma, Oncogene $\mathbf{2 0}$ (2001), 1525-1528.

[67] H. Matsumoto, M. Nagao, S. Ogawa, H. Kanehiro, M. Hisanaga, S. Ko, N. Ikeda, H. Fujii, F. Koyama, T. Mukogawa and Y. Nakajima, Prognostic significance of death-associated protein-kinase expression in hepatocellular carcinomas, $\mathrm{An}$ ticancer Res 23 (2003), 1333-1341.

[68] T. Mori, S.J. O'Day, N. Umetani, S. R. Martinez, M. Kitago, K. Koyanagi, C. Kuo, T.L. Takeshima, R. Milford, H.J. Wang, V.D. Vu, S.L. Nguyen and D.S.B. Hoon, Predictive utility of circulating methylated DNA in serum of melanoma patients receiving biochemotherapy, J Clin Oncol 23 (2005), 93519358.

[69] H.M. Muller, S. Millinger, H. Fiegl, G. Goebel, L. Ivarsson, A. Widschwendter, E. Muller-Holzner, C. Marth and M. Widschwendter, Analysis of methylated genes in peritoneal fluids of ovarian cancer patients: A new prognostic tool, Clin Chem 50 (2004), 2171-2173.

[70] H.M. Muller, M. Oberwalder, H. Fiegl, M. Morandell, G. Goebel, M. Zitt, M. Muhlthaler, D. Ofner, R. Margreiter and M. Widschwendter, Methylation changes in faecal DNA: a marker for colorectal cancer screening? Lancet 363 (2004), 1283-1285.

[71] H.M. Muller, A. Widschwendter, H. Fiegl, L. Ivarsson, G. Goebel, E. Perkmann, C. Marth and M. Widschwendter, DNA methylation in serum of breast cancer patients: An independent prognostic marker, Cancer Res 63 (2003), 76417645 .

[72] H. Nakagawa, G.J. Nuovo, E.E. Zervos, E.W. Martin, R. Salovaara, L.A. Aaltonen and A. de la Chapelle, Age-related hypermethylation of the 5 ' region of MLH1 in normal colonic mucosa is associated with microsatellite-unstable colorectal cancer development, Cancer Res 61 (2001), 6991-6995.

[73] H. Nakayama, K. Hibi, M. Taguchi, T. Takase, T. Yamazaki, Y. Kasai, K. Ito, S. Akiyama and A. Nakao, Molecular detection of p16 promoter methylation in the serum of colorectal cancer patients, Cancer Letters 188 (2002), 115-119.

[74] M. Nakayama, M.L. Gonzalgo, S. Yegnasubramanian, X.H. Lin, A.M. De Marzo and W.G. Nelson, GSTP1 CpG island hypermethylation as a molecular biomarker for prostate cancer, J Cell Biochem 91 (2004), 540-552. 
[75] K.A. Olaussen, J.C. Soria, Y.W. Park, H.J. Kim, S.H. Kim, J.Y. Ro, F. Andre and S.J. Jang, Assessing abnormal gene promoter methylation in paraffin-embedded sputum from patients with NSCLC, Eur J Cancer 41 (2005), 2112-2119.

[76] Z. Petko, M. Ghiassi, A. Shuber, J. Gorham, W. Smalley, M.K. Washington, S. Schultenover, S. Gautam, S.D. Markowitz and W.M. Grady, Aberrantly Methylated CDKN2A, MGMT, and MLH1 in Colon Polyps and in Fecal DNA from Patients with Colorectal Polyps, Clin Cancer Res 11 (2005), 1203-1209.

[77] G.Z. Qu, L. Dubeau, A. Narayan, M.C. Yu and M. Ehrlich, Satellite DNA hypomethylation vs. overall genomic hypomethylation in ovarian epithelial tumors of different malignant potential, Mutat Res 423 (1999), 91-101.

[78] M. Sanchez-Cespedes, M. Esteller, L. Wu, H. NawrozDanish, G.H. Yoo, W.M. Koch, J. Jen, J.G. Herman and D. Sidransky, Gene Promoter Hypermethylation in Tumors and Serum of Head and Neck Cancer Patients, Cancer Res 60 (2000), 892-895.

[79] S. Santourlidis, A. Florl, R. Ackermann, H.C. Wirtz and W.A. Schulz, High frequency of alterations in DNA methylation in adenocarcinoma of the prostate, Prostate 39 (1999), 166174.

[80] L.L. Shen, J.Y. Fang, D.K. Qiu, T.F. Zhang, J.M. Yang, S.S. Chen and S.D. Xiao, Correlation between DNA methylation and pathological changes in human hepatocellular carcinoma, Hepatogastroenterology 45 (1998), 1753-1759.

[81] J.M. Silva, G. Dominguez, M.J. Villanueva, R. Gonzalez, J.M. Garcia, C. Corbacho, M. Provencio, P. Espana and F. Bonilla, Aberrant DNA methylation of the p16(INK4a) gene in plasma DNA of breast cancer patients, Br J Cancer $\mathbf{8 0}$ (1999), 1262-1264.

[82] J.M. Silva, G. Dominguez, J.M. Garcia, R. Gonzalez, M.J. Villanueva, F. Navarro, M. Provencio, S. San Martin, P. Espana and F. Bonilla, Presence of Tumor DNA in Plasma of Breast Cancer Patients: Clinicopathological Correlations, Cancer Res 59 (1999), 3251-3256.

[83] J.C. Soria, M. Rodriguez, D.D. Liu, J.J. Lee, W.K. Hong and L. Mao, Aberrant Promoter Methylation of Multiple Genes in Bronchial Brush Samples from Former Cigarette Smokers, Cancer Res 62 (2002), 351-355.

[84] M. Stroun, J. Lyautey, C. Lederrey, A. Olson-Sand and P. Anker, About the possible origin and mechanism of circulating DNA - Apoptosis and active DNA release, Clin Chim Acta 313 (2001), 139-142.

[85] C.I. Suh, T. Shanafelt, D.J. May, K.R. Shroyer, J.B. Bobak, E.D. Crawford, G.J. Miller, N. Markham and L.M. Glode, Comparison of telomerase activity and GSTP1 promoter methylation in ejaculate as potential screening tests for prostate cancer, Mol Cell Probes 14 (2000), 211-217.

[86] C.M. Suter, D.I.K. Martin and R.L. Ward, Germline epimutation of MLH1 in individuals with multiple cancers, Nat Genet 36 (2004), 497-501.

[87] T. Sze Wong, H. Wen Chang, K. Chi Tang, W. Ignace Wei, D. Lai Wen Kwong, J.S.T. Sham, A.P.W. Yuen and Y. Lam Kwong, High Frequency of Promoter Hypermethylation of the Death-associated Protein-Kinase Gene in Nasopharyngeal Carcinoma and Its Detection in the Peripheral Blood of Patients, Clin Cancer Res 8 (2002), 433-437.

[88] D. Takai and P.A. Jones, Comprehensive analysis of $\mathrm{CpG}$ islands in human chromosomes 21 and 22, Proc Natl Acad Sci USA 99 (2002), 3740-3745.

[89] O. Topaloglu, M.O. Hoque, Y. Tokumaru, J. Lee, E. Ratovitski, D. Sidransky and C.S. Moon, Detection of Promoter Hypermethylation of Multiple Genes in the Tumor and Bronchoalveolar Lavage of Patients with Lung Cancer, Clin Cancer Res 10 (2004), 2284-2288.

[90] H. Usadel, J. Brabender, K.D. Danenberg, C. Jeronimo, S. Harden, J. Engles, P.V. Danenberg, S. Yang and D. Sidransky, Quantitative Adenomatous Polyposis Coli Promoter Methylation Analysis in Tumor Tissue, Serum, and Plasma DNA of Patients with Lung Cancer, Cancer Res 62 (2002), 371-375.

[91] M.T. Valenzuela, R. Galisteo, A. Zuluaga, M. Villalobos, M.I. Nunez, F.J. Oliver and J.M.R. de Almodovar, Assessing the use of p16(INK4a) promoter gene methylation in serum for detection of bladder cancer, Eur Urol 42 (2002), 622-628.

[92] M. van Rijnsoever, H. Elsaleh, D. Joseph, K. McCaul and B. Iacopetta, CpG Island Methylator Phenotype Is an Independent Predictor of Survival Benefit from 5-Fluorouracil in Stage III Colorectal Cancer, Clin Cancer Res 9 (2003), 2898-2903.

[93] Y.C. Wang, Y.P. Lu, R.C. Tseng, R.K. Lin, J.W. Chang, J.T. Chen, C.M. Shih and C.Y. Chen, Inactivation of hMLH1 and hMSH2 by promoter methylation in primary non-small cell lung tumors and matched sputum samples, J Clin Invest 111 (2003), 887-895.

[94] A. Widschwendter, C. Gattringer, L. Ivarsson, H. Fiegl, A. Schneitter, A. Ramoni, H.M. Muller, A. Wiedemair, S. Jerabek, E. Muller-Holzner, G. Goebel, C. Marth and M. Widschwendter, Analysis of aberrant DNA methylation and human papillomavirus DNA in cervicovaginal specimens to detect invasive cervical cancer and its precursors, Clin Cancer Res 10 (2004), 3396-3400.

[95] I.H.N. Wong, Y.M. Dennis Lo, W. Yeo, W.Y. Lau and P.J. Johnson, Frequent p15 Promoter Methylation in Tumor and Peripheral Blood from Hepatocellular Carcinoma Patients, Clin Cancer Res 6 (2000), 3516-3521.

[96] I.H.N. Wong, Y.M. Dennis Lo, J. Zhang, C.T. Liew, M.H.L. $\mathrm{Ng}$, N. Wong, P.B.S. Lai, W.Y. Lau, N.M. Hjelm and P.J. Johnson, Detection of Aberrant p16 Methylation in the Plasma and Serum of Liver Cancer Patients, Cancer Res 59, 71-73.

[97] I.H.N. Wong, J. Zhang, P.B.S. Lai, W.Y. Lau and Y.M. Dennis Lo, Quantitative Analysis of Tumor-derived Methylated p16INK4a Sequences in Plasma, Serum, and Blood Cells of Hepatocellular Carcinoma Patients, Clin Cancer Res 9 (1999), 1047-1052 (2003).

[98] T.S. Wong, M.W.L. Man, A.K.Y. Lam, W.I. Wei, Y.L. Kwong and A.P.W. Yuen, The study of p16 and p15 gene methylation in head and neck squamous cell carcinoma and their quantitative evaluation in plasma by real-time PCR, Eur J Cancer 39 (2003), 1881-1887.

[99] T.S. Wong, D.L.W. Kwong, J.S.T. Sham, W.I. Wei, Y.L. Kwong and A.P.W. Yuen, Quantitative Plasma Hypermethylated DNA Markers of Undifferentiated Nasopharyngeal Carcinoma, Clin Cancer Res 10 (2004), 2401-2406.

[100] H.Z. Zou, B.M. Yu, Z.W. Wang, J.Y. Sun, H. Cang, F. Gao, D.H. Li, R. Zhao, G.G. Feng and J. Yi, Detection of Aberrant p16 Methylation in the Serum of Colorectal Cancer Patients, Clin Cancer Res 8 (2002), 188-191. 


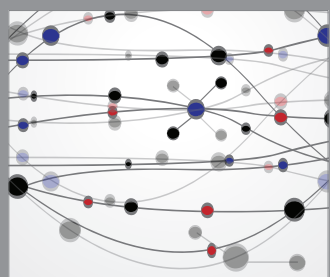

The Scientific World Journal
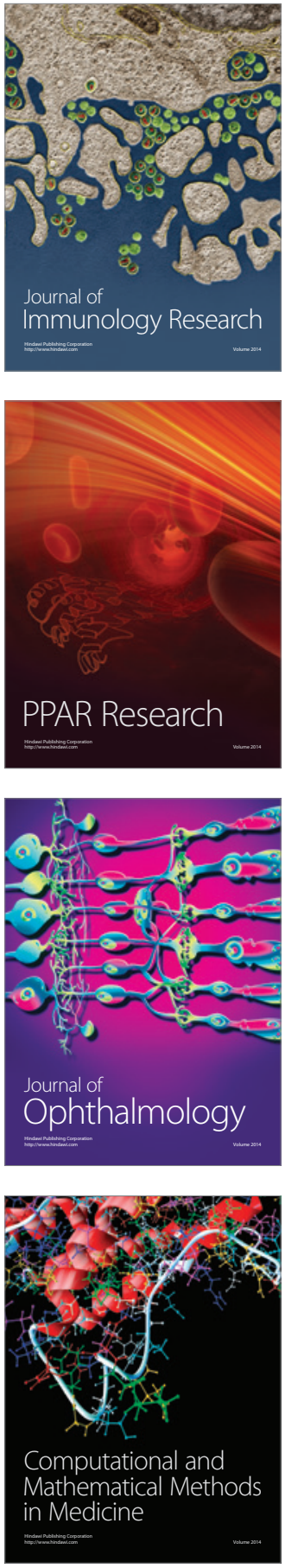

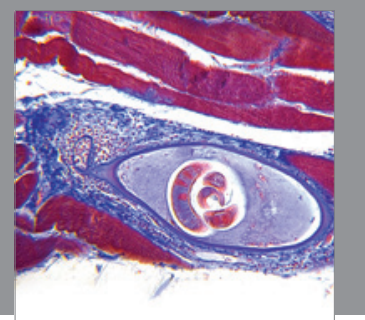

Gastroenterology

Research and Practice
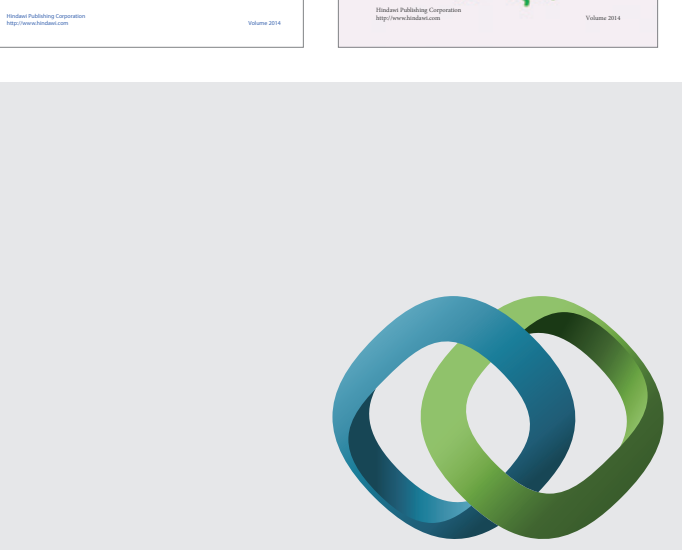

\section{Hindawi}

Submit your manuscripts at

http://www.hindawi.com
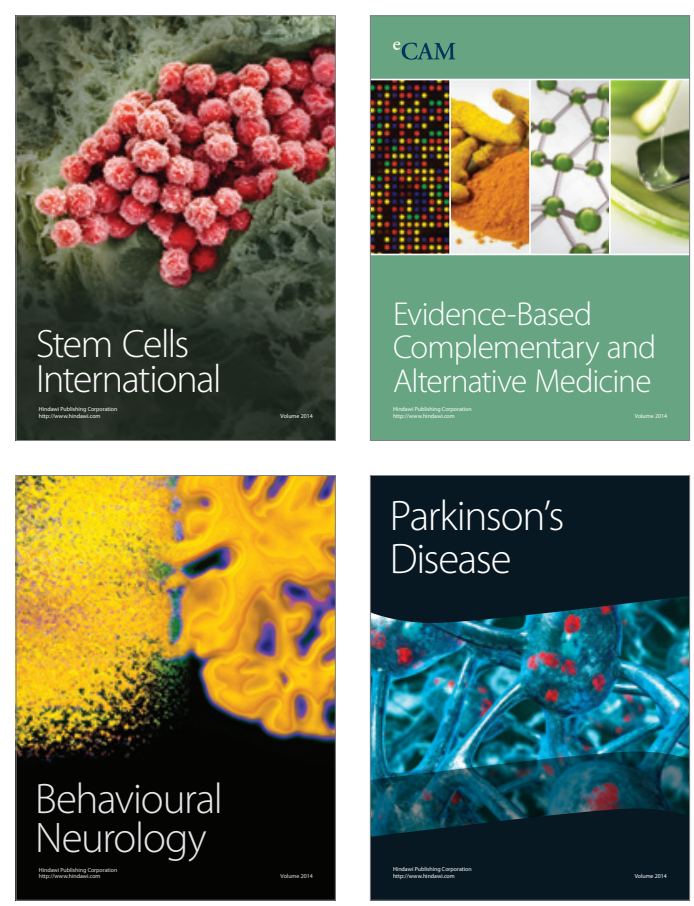

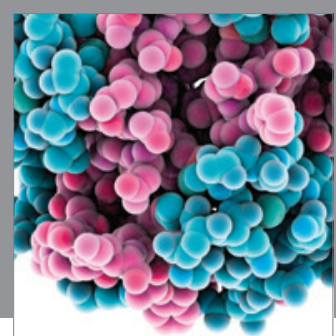

Journal of
Diabetes Research

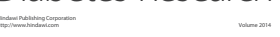

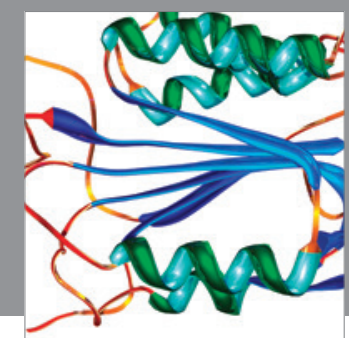

Disease Markers
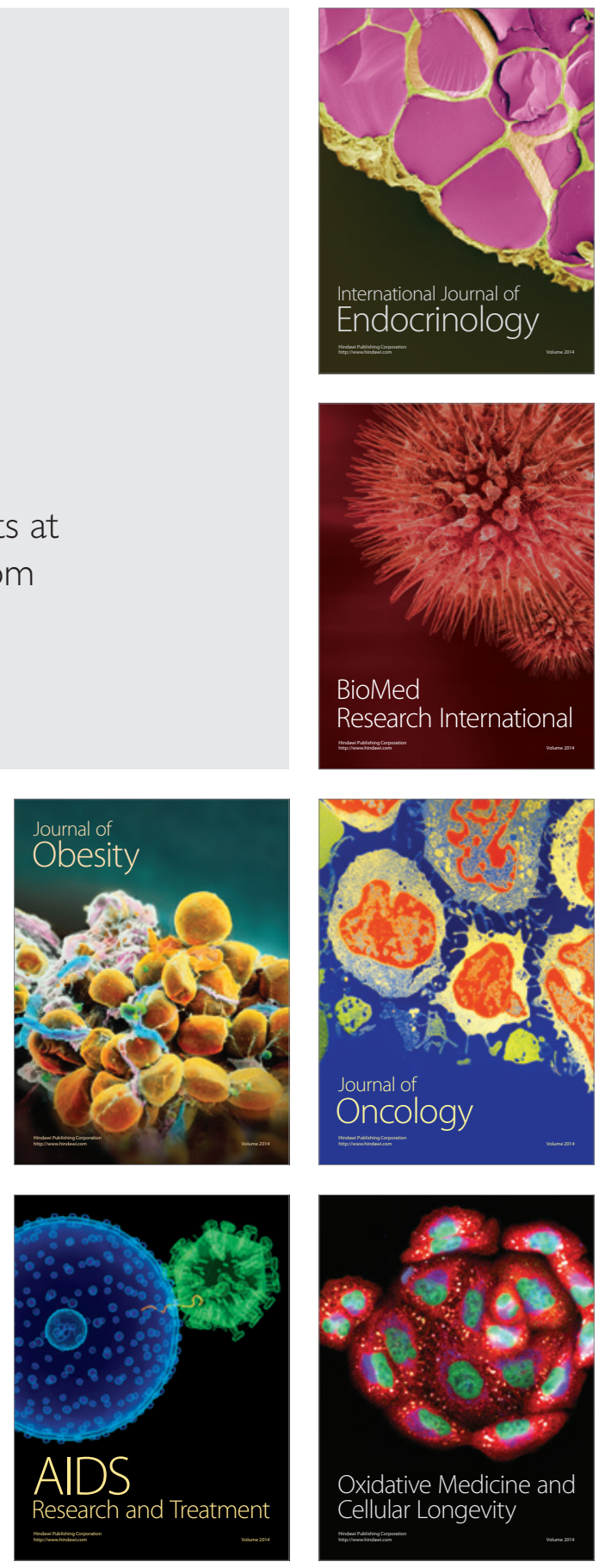